\title{
Earnings Differentials and Ownership Structure in Chinese Enterprises
}

\author{
YI CHEN \\ CERDI, Université d'Auvergne \\ SYLVIE DÉMURGER \\ HIEBS, University of Hong Kong, and CNRS-CERDI \\ MARTIN FOURNIER \\ CEFC (Hong Kong) and CERDI, Université d'Auvergne
}

\section{Introduction}

China's transition toward a market economy over the last 25 years has led to dramatic changes in every segment of the economy. Its increasing integration into the world economy as well as urban industrial reforms have profoundly modified urban labor market conditions by bringing in a wide range of institutionally and economically distinct enterprise types. Indeed, rather than massively privatizing state-owned enterprises (SOEs), the Chinese government has chosen to gradually reform the state sector while at the same time encouraging the emergence of a competing nonstate sector, especially through preferential policies toward foreign direct investment.

A major outcome of this gradual strategy in terms of industrial organization has been the coexistence of enterprises facing very different institutional and economic environments with, on the one hand, SOEs still operating according to the central administration plan or requirements and, on the other hand, nonstate enterprises having employment and wage settings mainly driven by market forces. Moreover, despite reforms being gradually carried out, the performance of SOEs kept deteriorating during the 1990s, leading to important financial losses and overstaffing (Lin, Cai, and $\mathrm{Li}$ 2001). At the same time, the impressive flow of foreign direct investment into China contributed to

We are grateful to Li Shi for providing access to the household income survey data used in the article. We are also indebted to Marc Gurgand, Hu Yifan, Li Shi, Scott Rozelle, and Zhao Yaohui, as well as to John Strauss and three anonymous referees, for useful comments on previous versions of the article.

(C) 2005 by The University of Chicago. All rights reserved. 0013-0079/2005/5304-0006\$10.00 
the rapid development of a flourishing joint-venture sector, concomitant with the emergence of a dynamic domestic private sector.

The interplay of these very different enterprises has affected the employment and wage structure in the Chinese urban labor market in various ways. A large number of papers have reported an overall rise in returns to education and higher returns to education in the nonstate sector (Maurer-Fazio 1999; Fu and Gabriel 2000; Li 2003). But, given the transitional context and the huge variations in ownership structure and management across enterprises, earnings remain strongly conditioned by institutional arrangements. As wagesetting behaviors depend on the market orientation of enterprises, we can expect the labor market in China to be not well integrated and earnings differentials to arise among enterprises of different ownership.

Several contrasting factors can be put forward both theoretically and empirically to explain these earnings differentials, making it unclear whether earnings in the state-owned sector should be above or below earnings in the nonstate sector (Tansel 2005). Indeed, on the one hand, the protected situation of SOEs in China may allow them to offer above-market wages (Putterman 1992) while, on the other hand, private and foreign enterprises may be offering higher remuneration in order to incorporate "efficiency wage" elements or to compensate for the loss of job security and lower nonwage benefits (Adamchick and Bedi 2000; Martins 2004). A key point in the understanding of China's economic and labor market transition and its welfare impact thus lies in the mechanisms leading wages to vary across firms of different ownership. ${ }^{1}$

A second major issue concerns the impact of a nonintegrated labor market on labor allocation. Although more market mechanisms and more flexibility have been brought into the Chinese labor market in the course of the reforms, spontaneous movements of the labor force out of loss-making SOEs have remained extremely low during the 1990s. Worsening losses and overstaffing reached unmanageable levels and resulted in massive layoffs at the end of the decade. Surprisingly, the issue of the causes of labor immobility across enterprises of different ownership has received little attention in the empirical literature on the Chinese urban labor market. A notable exception can be found in Zhao (2002), who highlights higher nonwage benefits provided by SOEs (e.g., pensions, housing, and health care) as a key explanation for labor immobility. Although her work sheds interesting light on the issue, several points still call for further analysis. First, Zhao's main results are derived from

${ }^{1}$ The issue of the extent and the causes of wage differentials between the public and private sectors has been explored recently for transition or developing economies (e.g., Adamchick and Bedi 2000; Falaris 2004; Tansel 2005). For urban China, the only works addressing this issue are Zhao (2001, 2002) and Dong and Bowles (2002). 
an ad hoc evaluation of nonwage benefits grossly estimated from aggregate statistics, which cannot directly match individual data on earnings. Second, the data used in her work do not include information on hours worked. In this article, we claim that segmentation issues have to be analyzed in terms of differences both in hourly earnings and in hours worked, and we show that the latter plays a central role in explaining earnings differentials across enterprises of different ownership in China, particularly between foreign-invested enterprises and large SOEs.

Our analysis is based on a household survey conducted by the Chinese Academy of Social Sciences (CASS), which provides detailed information on labor income as well as on individual and household characteristics for the year 1995. One of the key advantages of this data set is to provide information on individual income including nonwage benefits provided by SOEs and, most important, information on the number of hours worked. ${ }^{2}$

The objective of this article is thus to provide a broader overview of the forces at work in the Chinese urban labor market, using a database that allows for a better evaluation of direct nonwage benefits and taking into account differences in hours worked. We investigate earnings differentials among enterprises of different ownership and evaluate how much of observed earnings gaps can be attributed to differences in characteristics of workers, differences in hours worked, and incomplete labor market integration. Doing so, the article helps to shed light on the structure of the Chinese labor market after 10 years of reforms, on the extent to which the labor market had become market forces-driven, and on the potential explanations for the strong inertia affecting employment in overstaffed and loss-making SOEs.

The article is organized as follows. Section II briefly presents the evolution of the labor market in China over the last 2 decades. Section III provides some descriptive statistics on earnings differentials by enterprise ownership in 1995. Section IV proposes an extended form of Oaxaca-Blinder decompositions. Section $\mathrm{V}$ discusses econometric results for earnings functions and hours-worked equations, and Section VI presents decomposition results of observed earnings gaps between enterprises of different ownership. Section VII discusses our main findings and concludes the article.

\section{Labor Market Reforms and Segmentation in China}

Before reforms were launched at the end of the 1970s, there was basically no labor market in China. Job allocation and wage settings in SOEs were de-

${ }^{2}$ See Khan and Riskin (1998) for a detailed discussion of the advantages of these data over the data provided by the National Bureau of Statistics (NBS). 
termined within the central plan, and a key function held by SOEs was to provide employment and social benefits to the whole working-age population. The main features of the centrally determined wage structure were the following. ${ }^{3}$ First, the rigid wage determination system was based mostly on an egalitarian principle, wages were low, and promotion or wage increases were mostly driven by seniority. Moreover, SOEs also provided a number of social welfare benefits, including housing, medical care, and pensions, which aimed at compensating for low base wages. Finally, due to the employment assignment system and to the strictly controlled movement of the population within the household registration system (bukou), labor mobility was very limited between both sectors and regions.

Economic reforms launched at the end of the 1970s led to important changes within the state sector. In a first step, some autonomy in decision making for employment and wages was given to SOE managers. They were authorized to retain a share of their profits and use it to give bonus wages to their employees. Bonus wages were aimed at providing incentives to employees and increasing the overall productivity of SOEs. Their amounts were also supposed to reflect both enterprise and individual performances (Coady and Wang 2000; Meng 2000). However, due to high supervision costs, bonuses have often been distributed on an egalitarian basis within work units, and the evaluation of their impact remains controversial.

In the meantime, industrial reforms favored the emergence of the nonstate sector, composed of collective enterprises, foreign-invested enterprises, domestic private enterprises, individual enterprises (getibu), domestic joint ventures (lianying qiye), and share-holding companies (gufenzhi qiye). ${ }^{4}$ The share of the nonstate sector in employment grew steadily from 1978 onward and accounted for $35 \%$ in 1995.5 Although domestic private enterprises suffered from restricting policies such as overtaxation, strict regulation, and limited

${ }^{3}$ A detailed description of the prereform wage-setting system is given in Meng (2000, chap. 2). See also Lin et al. (2001).

${ }^{4}$ Firms with foreign ownership are of three types: joint ventures, firms that have entered into cooperation agreements, and wholly foreign-owned firms (Démurger 2000). In 1988, the State Council issued the Tentative Stipulations on Private Enterprises (TSPE) to govern the registration and management of private firms. This document defined a private firm as "a for-profit organization that is owned by individuals and employs more than eight people." Firms hiring eight employees or less could be registered as individual enterprises (getibu). The TSPE identified three types of private firms: those under sole ownership, partnerships, and limited liability companies. However, it was only in March 1999 that private ownership and the rule of law were formally incorporated into the Chinese constitution.

${ }^{5}$ In terms of industrial production, the growing importance of the nonstate sector is even more remarkable: the nonstate sector's share of manufacturing output increased from $22.4 \%$ in 1978 to $62.8 \%$ in 1995 . 
access to loans and skilled employees in the 1980s, the private sector (including foreign enterprises) became a leading engine of reforms and introduced market forces into the Chinese economy. Out of the central plan, these enterprises independently determine their employment policies and wage scales, and their behavior is mostly driven by profit-maximization objectives.

Changes in both the state-owned sector and the evolution of the nonstate sector have had significant impacts on labor allocation (Zhao 2002) as well as on income distribution among urban workers (Knight and Song 2003; Park et al. 2003). Given that wage setting systems greatly differ among enterprises of different ownership, we can expect earnings to be nonuniform among urban workers employed by different types of enterprises. Hence, as enterprises' objective functions vary considerably with ownership, with huge differences in terms of budget constraints between state and nonstate enterprises, segmentation is likely to be a key feature of the emerging Chinese urban labor market. $^{6}$

\section{Earnings Differentials in 1995: Some Descriptive Statistics Data Set and Variables Definition}

Our data come from the 1995 survey of the China Household Income Project (CHIP). These data were collected in 1996 by a team headed by the Institute of Economics, Chinese Academy of Social Sciences (Riskin, Zhao, and Li 2001). They cover 6,931 households and 21,694 individuals in urban China across 11 provinces. $^{7}$ The sample we use in this study is composed of 11,238 workers. We chose to restrict the sample to individuals aged 16-60 who declared

\footnotetext{
${ }^{6}$ A growing number of works have been studying changes in China's wage structure over the last decade. Recently, the larger availability of nationwide household surveys has allowed for deeper statistical analyses of the issue, focusing on various complementary aspects. A main area of research focuses on earnings gaps between different groups of workers, analyzing labor market segmentation between rural migrants and urban residents (Knight, Song, and Jia 1999; Meng and Zhang 2001; Maurer-Fazio and Dinh 2004) or discrimination against women (Gustafsson and Li 2000; Liu, Meng, and Zhang 2000). Most of these studies find that the ownership structure of enterprises is a significant explanatory factor of observed earnings gaps.

${ }^{7}$ The Chinese Household Income Project is a joint research effort sponsored by the Institute of Economics, Chinese Academy of Social Sciences, the Asian Development Bank, and the Ford Foundation. Additional support was provided by the East Asian Institute, Columbia University (Riskin, Zhao, and Li 2000). The sample includes the following provinces: Beijing, Shanxi, Liaoning, Jiangsu, Anhui, Henan, Guangdong, Yunnan, Sichuan, Gansu, and Hubei. Although another database from the CHIP is available for 1988, we chose to restrict our study to 1995 for two main reasons. First, the 1988 survey includes too few observations on foreign-invested enterprises to include them in the econometric model. The comparison between foreign-invested enterprises, which are believed to have more market-driven behaviors, and domestic enterprises is one of the main focuses of this work. Second, the 1988 data do not provide any information on the number of hours worked, which is also one of the main contributions of this article.
} 
working at least part of the year and earning (positive) wages. Owners of private or individual enterprises are not included in the sample, since we cannot disentangle wages from profit in their cases.

The earnings variable is defined as the sum of cash labor compensations and income in kind. Cash labor compensations include the basic salary, bonuses, allowances (except those given while "waiting for a job" [xiagang]) and subsidies (including housing, medical, child care, and regional subsidies), other wages (including overtime wages and wages for special circumstances), and other income from the work unit (except hardship allowances). Hourly earnings are defined as the ratio between total earnings and the number of declared hours worked in a year.

We consider five types of enterprise ownership: SOEs at the central or provincial level (CSOEs), local publicly owned enterprises (local SOEs), urban collective enterprises (UCEs), private or individual enterprises (PIEs), and foreign-invested enterprises (FIES; comprising both Sino-foreign joint ventures and foreign-owned enterprises). At the aggregate level, SOEs at the central or provincial level account for $9.3 \%$ of the total number of SOEs, while local publicly owned enterprises account for the remaining 90.7\%. However, SOEs at the central or provincial level have, on average, a larger size, since they employ $37.7 \%$ of the total labor force in the state-owned sector.

In a preliminary step, table 1 provides descriptive statistics on workers' characteristics by enterprise ownership. Mean tests reported in the table indicate significant differences in observable individual characteristics across enterprises of different ownership. On average, those working in SOEs at the central or provincial level are significantly older and more educated and have a significantly longer work experience than in any other type of enterprise. The SOEs at the central or provincial level also tend to employ significantly more male workers, as well as workers with a communist membership, but they are less predominantly located in coastal provinces. As opposed to both SOEs at the central or provincial level and local publicly owned enterprises, foreign-invested enterprises are more concentrated in the secondary sector and, unsurprisingly, mostly located in coastal areas. Workers' profiles in local publicly owned enterprises are very close to the average, while there are significantly less educated workers and male workers in urban collectives.

\section{Earnings Differentials by Ownership}

As can be seen from tables 2 and 3, total earnings, hourly earnings, and each earning component are significantly different across enterprise types. Total earnings are the highest in foreign-invested enterprises and the lowest in urban collectives. On average, annual earnings in foreign-invested enterprises in 1995 
TABLE 1

DESCRIPTIVE STATISTICS

\begin{tabular}{|c|c|c|c|c|c|c|c|c|c|c|c|}
\hline $\begin{array}{l}\text { Ownership } \\
\text { Categories }\end{array}$ & $\begin{array}{c}\text { All } \\
\text { Workers }\end{array}$ & $\begin{array}{l}\text { Central } \\
\text { SOEs } \\
(1)\end{array}$ & $\begin{array}{l}\text { Mean } \\
\text { Test }\end{array}$ & $\begin{array}{l}\text { Local } \\
\text { SOEs } \\
\text { (2) }\end{array}$ & $\begin{array}{l}\text { Mean } \\
\text { Test }\end{array}$ & $\begin{array}{l}\text { UCEs } \\
\text { (3) }\end{array}$ & $\begin{array}{l}\text { Mean } \\
\text { Test }\end{array}$ & $\begin{array}{l}\text { PIEs } \\
\text { (4) }\end{array}$ & $\begin{array}{l}\text { Mean } \\
\text { Test }\end{array}$ & $\begin{array}{l}\text { FIEs } \\
(5)\end{array}$ & $\begin{array}{c}\text { Mean } \\
\text { Test }\end{array}$ \\
\hline No. observations & 10,356 & 2,802 & & 5,717 & & 1,621 & & 86 & & 130 & \\
\hline Male & $52.9 \%$ & $60.2 \%$ & $2,3,4$ & $53.3 \%$ & 1,3 & $39.2 \%$ & $1,2,5$ & $45.3 \%$ & 1 & $54.6 \%$ & 3 \\
\hline Average age (years) & $\begin{array}{l}38.4 \\
(9.4)\end{array}$ & $\begin{array}{l}39.3 \\
(9.7)\end{array}$ & All & $\begin{array}{c}38.3 \\
(9.3)\end{array}$ & $1,4,5$ & $\begin{array}{l}37.9 \\
(8.8)\end{array}$ & $1,4,5$ & $\begin{array}{l}32.7 \\
(9.4)\end{array}$ & $1,2,3$ & $\begin{array}{c}31.1 \\
(10.0)\end{array}$ & $1,2,3$ \\
\hline Education (years) & $\begin{array}{l}11.5 \\
(2.7)\end{array}$ & $\begin{array}{l}12.0 \\
(2.7)\end{array}$ & $2,3,4$ & $\begin{array}{l}11.7 \\
(2.6)\end{array}$ & $1,3,4$ & $\begin{array}{l}10.0 \\
(2.5)\end{array}$ & $1,2,5$ & $\begin{array}{c}9.9 \\
(2.6)\end{array}$ & $1,2,5$ & $\begin{array}{l}11.5 \\
(2.5)\end{array}$ & 3,4 \\
\hline Communist & $24.7 \%$ & $29.0 \%$ & All & $26.9 \%$ & All & $12.0 \%$ & $1,2,4$ & $3.5 \%$ & All & $9.2 \%$ & $1,2,4$ \\
\hline Coast & $26.0 \%$ & $19.9 \%$ & All & $26.1 \%$ & All & $32.1 \%$ & All & $41.9 \%$ & $1,2,3$ & $66.9 \%$ & $1,2,3$ \\
\hline Secondary sector & $45.9 \%$ & $43.1 \%$ & All & $42.3 \%$ & All & $63.2 \%$ & 1,2 & $17.4 \%$ & $1,2,5$ & $61.5 \%$ & $1,2,4$ \\
\hline Tertiary sector & $51.4 \%$ & $51.5 \%$ & All & $55.6 \%$ & All & $35.6 \%$ & $1,2,4$ & $82.6 \%$ & All & $38.5 \%$ & $1,2,4$ \\
\hline
\end{tabular}

Source. Authors' calculations using the 1995 CHIP survey data.

Note. The five categories are central or provincial state-owned enterprises (SOEs), local SOEs, urban collective enterprises (UCEs), private or individual enterprise (PIEs), and foreign-invested enterprises (FIEs). Experience is the number of years of work experience declared by the respondent. The coastal region includes Beijing, Guangdong and Jiangsu. The secondary sector includes both industry and construction. Mean tests columns indicate enterprises' categories (numbered 1-5) against which a given variable's mean is significantly different (at the $5 \%$ level). Standard deviations are in parentheses. 
TABLE 2

AVERAGE ANNUAL EARNINGS BY OWNERSHIP AND ITS COMPONENTS

\begin{tabular}{|c|c|c|c|c|c|c|}
\hline Ownership Categories & Central SOEs & Local SOEs & UCEs & PIEs & FIEs & F-test \\
\hline No. observations & 3,094 & 6,182 & 1,702 & 113 & 147 & 11,238 \\
\hline Earnings & 6,997 & 6,140 & 4,795 & 5,208 & 8,213 & $102.4^{\star}$ \\
\hline Basic wage & 4,021 & 3,519 & 3,077 & 4,867 & 6,528 & $109.5^{\star}$ \\
\hline$\%$ & 57.5 & 57.3 & 64.2 & 93.5 & 79.5 & \\
\hline Bonus & 1,044 & 996 & 730 & 213 & 929 & $13.0^{\star}$ \\
\hline$\%$ & 14.9 & 16.2 & 15.2 & 4.1 & 11.3 & \\
\hline Subsidies & 1,323 & 1,088 & 631 & 58 & 479 & $113.5^{\star}$ \\
\hline$\%$ & 18.9 & 17.7 & 13.2 & 1.1 & 5.8 & \\
\hline Income in kind & 118 & 92 & 67 & 70 & 87 & $10.1^{*}$ \\
\hline$\%$ & 1.7 & 1.5 & 1.4 & 1.3 & 1.1 & \\
\hline
\end{tabular}

Source. Authors' calculations using the 1995 CHIP survey data.

Note. See table 1 for the list of categories. The sample includes individuals aged 16-60 who declared working at least a part of the year and earning (positive) wages. Owners of private or individual enterprises are not considered. The earnings variable is computed as the sum of the basic salary, bonuses, allowances and subsidies, other wages, other income from work unit, and income in kind. The F-tests (col. 6) test the hypothesis that a given variable mean is equal over all enterprise types.

* Indicates rejection of the equality hypothesis at the $1 \%$ level.

TABLE 3

TOTAL EARNINGS, HOURLY EARNINGS, AND NUMBER OF HOURS WORKED IN 1995

\begin{tabular}{lcccccr}
\hline Ownership Categories & Central SOEs & Local SOEs & UCEs & PIEs & FIEs & F-test \\
\hline No. observations & 3,094 & 6,182 & 1,702 & 113 & 147 & 11,238 \\
Average earnings & 6,997 & 6,140 & 4,795 & 5,208 & 8,213 & $102.4^{\star}$ \\
& $(.51)$ & $(.59)$ & $(.68)$ & $(.92)$ & $(.76)$ & \\
Average hourly earnings & 3.49 & 3.02 & 2.41 & 2.04 & 3.73 & $75.5^{\star}$ \\
& $(.64)$ & $(.71)$ & $(.83)$ & $(.996)$ & $(.80)$ & \\
Hours worked per week & 41.4 & 42.3 & 43.3 & 56.0 & 47.0 & $51.4^{\star}$ \\
& $(.17)$ & $(.18)$ & $(.22)$ & $(.29)$ & $(.19)$ & \\
\hline
\end{tabular}

Source. Authors' calculations using the 1995 CHIP survey data.

Note. See table 1 for the list of categories. The sample includes individuals aged 16-60 who declared working at least a part of the year and earning (positive) wages. Owners of private or individual enterprises are not considered. The earnings variable is computed as the sum of the basic salary, bonuses, allowances and subsidies, other wages, other income from work unit, and income in kind. The F-tests (col. 6) test the hypothesis that a given variable mean is equal over all enterprise types. Hours worked per week are calculated by multiplying the number of hours worked on an average day by the average number of work days per week in 1995. Coefficient of variations are in parentheses.

* Indicates rejection of the equality hypothesis at the $1 \%$ level.

are $71 \%$ higher than in urban collectives, $58 \%$ higher than in private or individual enterprises, $34 \%$ higher than in local SOEs, and $17 \%$ higher than in SOEs at the central or provincial level. Mean tests confirm that workers from foreign-invested enterprises earn significantly more than workers from SOEs at the central or provincial level, and that the latter earn significantly more than workers from local publicly owned enterprises. Workers from urban collectives and private or individual enterprises come last, the difference between the two categories being not significant.

The decomposition of earnings by components confirms that including nonwage benefits is essential when accounting for differences between the state 
and the nonstate sectors (Zhao 2002). Although our data set certainly still underestimates nonwage benefits, separate questions asked in the survey allow for the decomposition of total earnings by components and the estimation of the respective shares of bonuses, subsidies, and income in kind in total earnings. ${ }^{8}$ Table 2 shows that the highest levels of bonuses and subsidies are obtained in SOEs, as compared to the nonstate sector (both domestic and foreign). Indeed, subsidies accounted for nearly $20 \%$ of earnings paid by SOEs in 1995 .

These results are quite usual in the literature and seem to be common knowledge for Chinese workers. However, taking into account the number of hours worked leads to quite different and rarely mentioned results. Indeed, table 3 shows that average hourly earnings are significantly higher in both foreign-invested enterprises and SOEs at the central or provincial level, but the difference between the two categories is no longer significant. Indeed, although foreign-invested enterprises offer higher total annual earnings, their employees work significantly more than in the state sector, which reduces considerably the difference in hourly earnings between the two categories.

\section{Earnings Distribution by Ownership}

Coefficients of variation given in table 3 reveal that the highest differences among workers are observed in private or individual enterprises, while they are the lowest in SOEs at the central or provincial level. These findings are consistent with the fact that private enterprises include very different types of units, from tiny street shops to small-scale factories. They are corroborated by kernel density estimations for the distribution of income by ownership category for the logarithm of total earnings (fig. 1) and for the logarithm of hourly earnings (fig. 2), respectively. Each graph shows the distribution for the whole sample as well as for ownership category subsamples.

Kernel densities show a more concentrated earnings distribution for SOEs and urban collectives with thin distribution tails, whereas private or individual enterprises and foreign-invested enterprises have a much wider earnings distribution. Figure 1 also seems to show a bimodal distribution for FIEs' earnings, with a lower second mode at lower wage levels. This result is consistent with the hypothesis of Zhao (2001) of a segmented labor market between highand low-educated workers within FIEs. However, once working hours are taken into account, the distribution is no longer bimodal (fig. 2). This implies that

\footnotetext{
${ }^{8}$ As mentioned in Bramall (2001), one of the main improvements brought in the CHIP data, as compared to the NBS data, is the inclusion of a wider range of subsidies in urban income. However, Bramall also points out that this revised estimation of earnings still "vastly under-states the true value of urban subsidies" (701).
} 


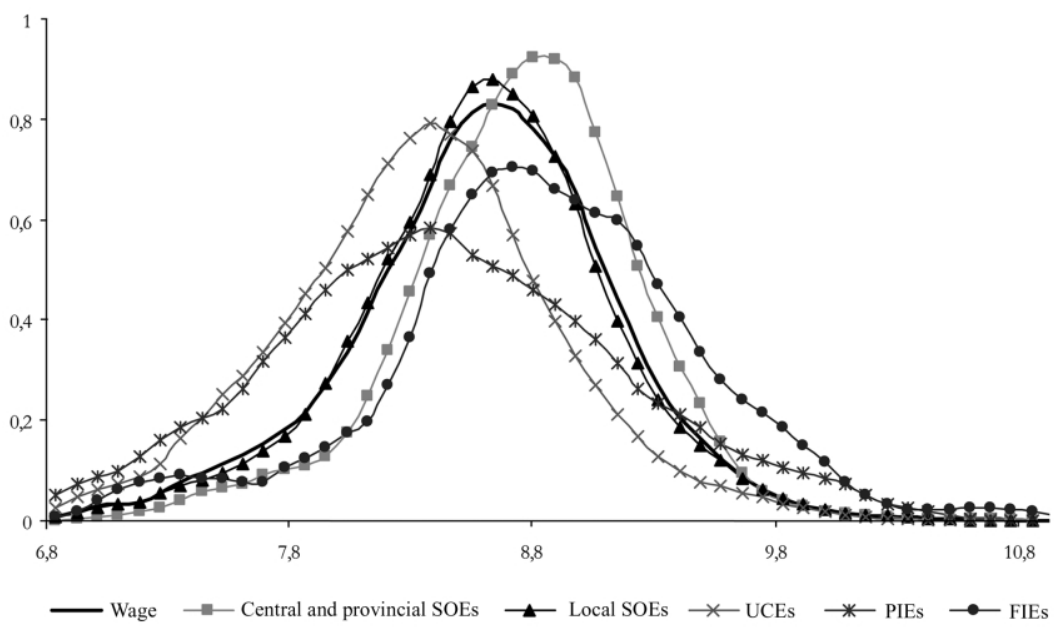

Figure 1. Kernel density of total earnings by ownership. In order to better visualize the density distribution, the logarithm of total earnings is considered only for those with total earnings above 1,000 yuan. Wage represents the total earnings distribution of the whole sample. Local SOEs refer to local publicly owned enterprises, UCEs to urban collective enterprises, PIEs to private or individual enterprises, and FIEs to foreign invested enterprises.

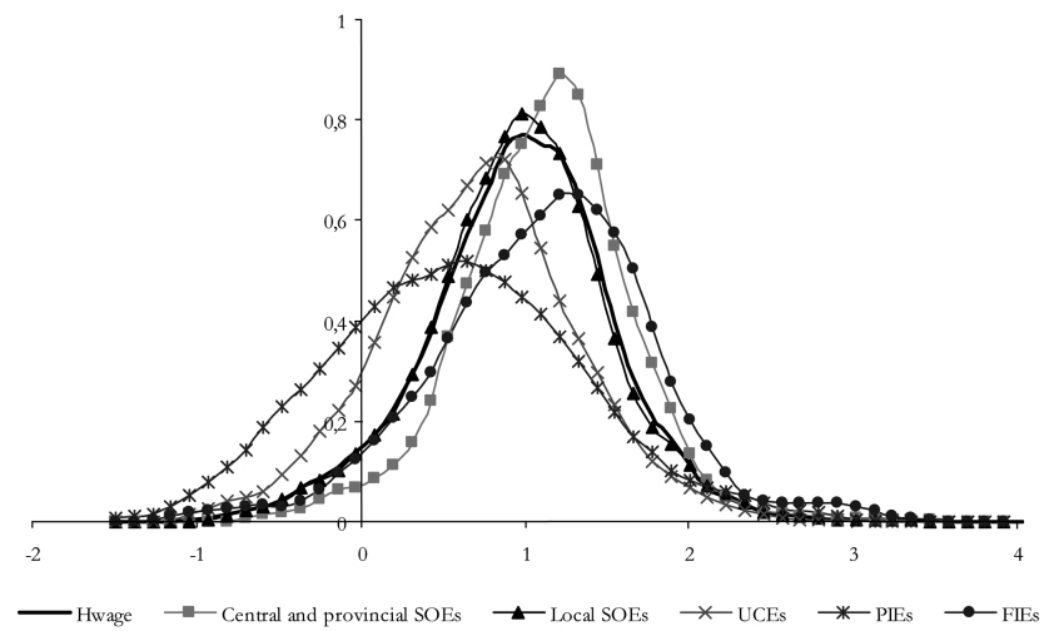

Figure 2. Kernel density of hourly earnings by ownership. See fig. 1; Hwage represents the hourly earnings distribution of the whole sample.

apparent higher earnings in FIEs for highly educated workers are to be attributed to some extent to longer working hours.

Kernel density estimations for hourly earnings further illustrate our findings on differences in average earnings for SOEs and FIEs. Indeed, the difference between SOEs at the central or provincial level and FIEs observed for total earnings (fig. 1) is much reduced for hourly earnings. Figure 2 actually shows 
that the main difference between the two distributions is the greater variance within FIEs. Indeed, FIEs hire more workers at lower as well as at higher hourly earnings than SOEs at the central and provincial level, the modes for the two distributions being quite similar. Hence, although FIEs provide higher earnings, especially for highly educated workers, they have a wider wage scale and offer more below-average earnings than SOEs.

\section{Methodology for Analyzing Earnings Differentials by Enterprise Ownership}

Our objective is to explain observed earnings disparities among enterprises of different ownership using an extended version of Oaxaca-Blinder-type decomposition methods (Blinder 1973; Oaxaca 1973). ${ }^{9}$ The basic idea of the decomposition technique is to propose counterfactual situations corresponding to income that would be earned by workers observed in an enterprise had they been facing the income generating model observed for an enterprise of different ownership. By "income generating model" we refer to the mechanisms through which individual income is determined by economic mechanisms, given a worker's socioeconomic characteristics. For example, a difference between observed income for SOE workers and the counterfactual income that the same workers would have obtained under the "foreign enterprises model" provides an evaluation of the segmentation that occurs between these two types of enterprises. Indeed, if markets were fully integrated, income under the SOE model (observed income) should be equal to income under the FIE model (counterfactual) for any given socioeconomic characteristics. The following decompositions distinguish three sources for the observed earnings gap: differences in characteristics, differences in hours worked, and a "pure ownership" difference. ${ }^{10}$

\section{Decomposing Hourly Earnings Differences across Enterprise Types}

Formally, let $w_{s}^{i}$ represent the hourly earnings of individual $i$ belonging to enterprise type $s$. Without loss of generality, $w_{s}^{i}$ may be assumed to depend on three sets of arguments: (i) individual observable sociodemographic characteristics or those of his or her household $(x)$, (ii) unobservable characteristics $(\varepsilon)$, and (iii) a set of parameters corresponding to the income model linking sociodemographic characteristics to observed income $(\beta)$.

\footnotetext{
${ }^{9}$ Extensions of this type of decomposition have recently been developed (see Bourguignon et al. 2001).

${ }^{10}$ We prefer to use the "pure ownership-difference" terminology instead of "segmentation" since, as we will see below, it might also include mechanisms not strictly related to segmentation.
} 
The hourly earnings generating process can be expressed as a function $W$ of these three sets of arguments: ${ }^{11}$

$$
w_{s}^{i}=W\left(x_{s}^{i}, \varepsilon_{s}^{i} ; \beta_{s}\right)
$$

Within this framework, observed differences in average hourly earnings between two given types of enterprises may come from two potential sources: (i) differences in average sociodemographic characteristics of workers between the two types of enterprises and (ii) differences in wage generating models between the two types of enterprises.

The first source of difference, $i$, corresponds to market-based differences in earnings, differences in sociodemographic characteristics such as education or experience leading to differences in average earnings. Different types of enterprises being specialized in different types of activities, the sociodemographic structure of workers naturally differs. Identifying source ii reveals a segmentation process, since the same individual is given different earnings depending on which type of enterprises he or she is working for.

Observed hourly earnings differences are thus decomposed into these two components as follows (two enterprise types: $s$ and $f$ ):

Pure difference-in-characteristics effect:

$$
E_{s f}^{i}=W\left(x_{s}^{i}, \varepsilon_{s}^{i} ; \beta_{s}\right)-W\left(x_{f}^{i}, \varepsilon_{f}^{i} ; \beta_{s}\right)
$$

Pure ownership difference:

$$
S_{s f}^{i}=W\left(x_{s}^{i}, \varepsilon_{s}^{i} ; \beta_{s}\right)-W\left(x_{s}^{i}, \varepsilon_{s}^{i} ; \beta_{f}\right) .
$$

The pure difference-in-characteristics effect $E_{s f}^{i}$ corresponds to the difference in income between workers of enterprise type $s$ and workers of enterprise type $f$ due to differences in the structure of individual characteristics $x$, controlling for differences in remuneration of those characteristics (all individuals are facing the same remuneration vector $\beta_{s}$ ). Symmetrically, the pure ownership difference $S_{s f}^{i}$ corresponds to the difference in hourly earnings due to differences in remuneration of individual characteristics between enterprises $s$ and $f$, for a given structure of characteristics $x$ (that observed for workers in enterprise type $s$ ). The formulation can then be averaged to evaluate the overall mean effect.

\footnotetext{
${ }^{11}$ The function $W$ thus represents the specification chosen for the wage generating model.
} 


\section{Introducing the Impact of Differences in Hours Worked}

We have stressed above the existence of strong differences in the number of hours worked across enterprises of different ownership. This dimension can be included into the approach. Total earnings for individual $i$ working in enterprise $s\left(I_{s}^{i}\right)$ is the product of the hourly earnings $\left(w_{s}^{i}\right)$ and the number of hours worked $\left(b_{s}^{i}\right)$ :

$$
I_{s}^{i}=h_{s}^{i} \times w_{s}^{i},
$$

where $h_{s}^{i}$ can be modeled for each enterprise type $s$ as a function $H$ of individual observable and unobservable characteristics $\left(z_{s}^{i}\right.$ and $\left.\eta_{s}^{i}\right)$ with parameters $\gamma_{s}$ :

$$
h_{s}^{i}=H\left(z_{s}^{i}, \eta_{s}^{i} ; \gamma_{s}\right)
$$

Along the same lines as presented above for hourly earnings, observed differences in total earnings between two given types of enterprises ( $s$ and $f$ ) may thus be decomposed into three components as follows:

Pure difference-in-characteristics effect:

$$
I E_{s f}^{i}=H\left(z_{s}^{i}, \eta_{s}^{i} ; \gamma_{s}\right) \times W\left(x_{s}^{i}, \boldsymbol{\varepsilon}_{s}^{i} ; \beta_{s}\right)-H\left(z_{f}^{i}, \eta_{f}^{i} ; \gamma_{s}\right) \times W\left(x_{f}^{i}, \boldsymbol{\varepsilon}_{f}^{i} ; \beta_{s}\right) .
$$

Pure ownership difference:

$$
I O_{s f}^{i}=H\left(z_{s}^{i}, \eta_{s}^{i} ; \gamma_{s}\right) \times W\left(x_{s}^{i}, \varepsilon_{s}^{i} ; \beta_{s}\right)-H\left(z_{s}^{i}, \eta_{s}^{i} ; \gamma_{s}\right) \times W\left(x_{s}^{i}, \varepsilon_{s}^{i} ; \beta_{f}\right) .
$$

Pure difference-in-hours-worked effect:

$$
I H_{s f}^{i}=H\left(z_{s}^{i}, \eta_{s}^{i} ; \gamma_{s}\right) \times W\left(x_{s}^{i}, \varepsilon_{s}^{i} ; \beta_{s}\right)-H\left(z_{s}^{i}, \eta_{s}^{i} ; \gamma_{f}\right) \times W\left(x_{s}^{i}, \varepsilon_{s}^{i} ; \beta_{s}\right) .
$$

\section{Path Dependency, Robustness Tests, and Practical Implementation}

This approach follows the well-known Oaxaca-Blinder decomposition methodology. A common problem with this methodology lies in path dependency. Since computed effects are likely to depend on the reference population used (Fournier 2005), it is generally the case that

$$
I E^{s f} \neq I E^{f_{s}} \text { and } I O^{s f} \neq I O^{f s} \text { and } I H^{s f} \neq I H^{f_{s}} .
$$

Moreover, the decompositions presented above can be run sequentially, every sequence leading to potentially different results, since evaluations are based on different reference populations and coefficient vectors. Overall, each of the three effects can be evaluated in four different ways, depending on the base population and the sequence chosen. In the application that follows, we take 
into account all alternative evaluations for each effect and use them as a robustness test for our decomposition results.

The implementation of the decomposition methodology is run in three steps. We first estimate the remuneration structure of each type of enterprise as well as equations for the number of hours worked. We then simulate counterfactual incomes for each observed worker, using each potential model for earnings and hours worked. Finally, we compute average counterfactual incomes under all combinations.

\section{Estimations Results Earnings Functions}

Table 4 presents Mincerian (hourly) earnings functions (Mincer 1974) estimated by enterprise ownership and by gender in 1995. To assess how much the pay structure varies across enterprises of different ownership, we proceed in two steps. First, we estimate the raw wage differentials across ownership by first including only ownership dummies for the whole sample (col. 1), and then adding covariates (col. 2). These estimations confirm results presented in table 3. Indeed, the dummy variables coefficients are significantly different across enterprises of different ownership. Furthermore, the dummy variable coefficients for enterprise ownership are significantly modified when covariates are included in the estimation, and Chow tests performed to test the null hypothesis that the $\beta$-coefficients in earnings equations between two different ownerships are the same indicate that the null hypothesis can be rejected at the $1 \%$ level for all couples of enterprises. We therefore ran separate estimations by enterprise ownership (cols. 3-8). The specification includes human capital characteristics (education and experience) and a geographical residence dummy. ${ }^{12}$

Since the choice of enterprise and the related expected remuneration are closely linked, estimating earnings functions for enterprises of different ownership should require controlling for potential selection biases. However, we decided here to treat enterprise's choice as exogenous for two reasons. First, since labor was still administratively allocated in China up to 1995, the enterprise's choice cannot be fully considered as the result of an individual choice. ${ }^{13}$ Second, achieving identification for enterprise's choice is problematic,

12 The reference for regional location is the noncoastal region. Many studies on the wage structure in China also include Communist Party membership as well as economic sector dummies. We chose to withdraw these two dimensions for endogeneity reasons, since no valid instrument could be found. However, all our results are robust to the inclusion of these variables in the specification.

${ }^{13}$ Using a 1996 urban household survey, Zhao (2002) also finds ordinary least squares (OLS) estimates of wage equations not seriously biased by enterprise selection. 
TABLE 4

EARNINGS FUNCTIONS

\begin{tabular}{|c|c|c|c|c|c|c|c|c|c|c|c|c|}
\hline & \multicolumn{2}{|c|}{$\begin{array}{c}\text { All Enterprises } \\
\text { (No Covariates) }\end{array}$} & \multicolumn{2}{|c|}{$\begin{array}{c}\text { All Enterprises } \\
\text { (Covariates) }\end{array}$} & \multicolumn{2}{|c|}{ Central SOEs } & \multicolumn{2}{|c|}{ Local SOEs } & \multicolumn{2}{|c|}{ UCEs } & \multicolumn{2}{|c|}{ FIEs } \\
\hline & Men & Women & Men & Women & Men & Women & Men & Women & Men & Women & Men & Women \\
\hline \multirow[t]{2}{*}{ Education } & & & .043 & .056 & .028 & .055 & .048 & .059 & .054 & .05 & .072 & .077 \\
\hline & & & 15.51 & 16.43 & 6.26 & 8.42 & 13.42 & 12.60 & 5.27 & 5.97 & 1.93 & 2.84 \\
\hline \multirow[t]{2}{*}{ Experience } & & & .049 & .068 & .043 & .056 & .05 & .074 & .07 & .071 & -.005 & .038 \\
\hline & & & 17.87 & 18.12 & 9.28 & 7.62 & 14.07 & 14.49 & 7.30 & 8.04 & -.15 & 1.42 \\
\hline \multirow[t]{2}{*}{ Experience $^{2}$} & & & -.0007 & -.0013 & -.0006 & -.0009 & -.0007 & -.0014 & -.0013 & -.0016 & .0006 & -.0003 \\
\hline & & & -10.97 & -12.41 & -5.26 & -4.42 & -8.66 & -10.11 & -5.56 & -6.34 & .59 & -.36 \\
\hline \multirow[t]{2}{*}{ Coast } & & & .423 & .424 & .351 & .37 & .472 & .409 & .377 & .508 & .338 & .47 \\
\hline & & & 25.42 & 21.81 & 11.37 & 8.85 & 22.45 & 15.79 & 6.92 & 11.87 & 1.81 & 3.29 \\
\hline \multirow[t]{2}{*}{ CSOEs } & 1.144 & 1.010 & -.101 & -.455 & & & & & & & & \\
\hline & 75.42 & 50.16 & -2.21 & -8.14 & & & & & & & & \\
\hline \multirow[t]{2}{*}{ LSOEs } & .991 & .856 & -.267 & -.612 & & & & & & & & \\
\hline & 89.43 & 66.70 & -6.00 & -11.42 & & & & & & & & \\
\hline \multirow[t]{2}{*}{ UCEs } & .747 & .596 & -.465 & -.793 & & & & & & & & \\
\hline & 30.88 & 28.33 & -10.26 & -15.40 & & & & & & & & \\
\hline \multirow[t]{2}{*}{ FIEs } & 1.073 & 1.046 & -.138 & -.384 & & & & & & & & \\
\hline & 14.95 & 12.23 & -1.86 & -4.30 & & & & & & & & \\
\hline \multirow[t]{2}{*}{ Constant } & & & & & .131 & -.374 & -.36 & -.686 & -.687 & -.698 & -.089 & -.512 \\
\hline & & & & & 1.73 & -3.59 & -6.32 & -9.49 & -4.84 & -6.26 & -.17 & -1.31 \\
\hline No. observations & 5,261 & 4,723 & 5,261 & 4,723 & 1,588 & 1,065 & 2,977 & 2,622 & 625 & 977 & 71 & 59 \\
\hline Adjusted $R^{2}$ & .74 & .63 & .80 & .71 & .22 & .23 & .29 & .23 & .20 & .22 & .04 & .31 \\
\hline Wage peak & & & 35 & 26 & 36 & 32 & 36 & 26 & 27 & 22 & NS & NS \\
\hline
\end{tabular}

Note. The dependent variable is the logarithm of hourly earnings. The four categories are central or provincial state-owned enterprises (CSOEs), local SOEs (LSOEs), urban collective enterprises (UCEs), and foreign-invested enterprises (FIEs). The reference category for regional location is the noncoastal region. The coastal dummy variable takes a value of one for Beijing, Guangdong, and Jiangsu. The estimated wage peaks from the coefficients of Experience and Experience ${ }^{2}$ are given in years of experience. 
since no available variable can be considered as a fully exogenous instrument. ${ }^{14}$ However, it should be stressed here that there may be selectivity problems that we do not account for, which calls for a cautious interpretation of our estimations results.

We also chose not to estimate earnings functions for workers in private or individual enterprises and thus dropped them from the subsequent analysis for the following reasons. First, our analysis is restricted to workers earning a salary. Since most private or individual enterprises are of a very small size, eligible observations were too few to estimate consistent earnings functions for this category. Second, private or individual enterprises include very different economic situations, which are difficult to account for in the estimation without further splitting the sample.

Earnings functions estimations reported in table 4 show significantly higher returns to education in foreign-invested enterprises. In terms of gender differences, returns to education are higher for women than for men in both SOEs at the central or provincial level and local publicly owned enterprises, while similar in urban collectives and in foreign-invested enterprises. For men, returns to education are significantly lower in SOEs at the central or provincial level, while for women, returns to education are not significantly different between SOEs at the central or provincial level, local publicly owned enterprises, and urban collectives. Compared to Dong and Bowles (2002), we find higher returns to education, ranging from $3 \%$ to $7 \%$ for one additional year of schooling, depending on enterprise ownership. ${ }^{15}$ Our results are, however, consistent with Zhao (2002), Li (2003), and Yueh (2004). ${ }^{16}$

The usual concave form for actual work experience is found for SOEs and urban collectives, but returns to experience are not significant for foreign-

${ }^{14}$ In an attempt to control for possible selectivity bias, we also estimated selectivity-corrected earnings functions, with correction terms identification being provided by the county-level share of each enterprise type in local employment and by information on household structure. Our main results from OLS estimations are robust to these changes. A working paper containing results from selectivity-corrected regressions may be downloaded from http://www.hiebs.hku.hk/working _papers.asp? ID $=97$.

${ }^{15}$ Their estimation is based on 1998 enterprise survey data from Dalian and Xiamen. Their estimated rate of returns to education is $2.3 \%$, and they find none of the interactive ownership dummies on human capital variables to be statistically significant.

${ }^{16}$ Using the same database (CHIP) for 1995, Li (2003) gets an overall return to education of $5.3 \%$ for hourly wages. Moreover, taking together private or individual enterprises and foreign-invested enterprises as the private sector, he finds that the private sector rewards the highly educated more, while the state-owned sector rewards the less educated more. Yueh (2004) also finds that in 1995 an additional year of education is associated with a $4 \%$ increase in income. In a 1996 urban household survey, Zhao (2002) finds the returns to education to be $4.2 \%$ for SOEs, $3.2 \%$ for collective enterprises, and $7.9 \%$ for foreign-invested enterprises. 
invested enterprises. ${ }^{17}$ The estimation of separate earnings functions by ownership shows that wage peaks are not uniform across ownership and gender (bottom row of table 4). First, differences between men and women can be observed with steeper but more concave returns to experience for women in all enterprise types. Women thus reach their wage peak on average 4-10 years earlier than men, depending on the enterprise type. The same order of difference between men and women has been found on pooled data for all types of enterprises by Li (2003). Moreover, differences in wage peaks between SOEs and urban collectives show that, in the former, returns to experience do not show any decreasing pattern for men, since the maximum earning is obtained for 36 years of experience. This result is consistent with Meng and Kidd (1997), who find that the experience profile rises continuously until retirement in the state-owned sector. ${ }^{18}$ Lower wage peaks found by Knight and Song (2003), $\mathrm{Li}$ (2003), and Yueh (2004) are more in line with wage peaks in urban collectives. ${ }^{19}$ The observed difference in experience earnings profiles between SOEs and urban collectives can be interpreted in terms of market forces at work in the determination of wages. It suggests that in 1995 market forces were playing a stronger role in urban collectives than in SOEs, where the resistance to changes in wage determination (particularly concerning seniority rewarding) is stronger. Finally, the absence of significant returns to experience in foreign-invested enterprises can certainly be attributed to the fact that workers in these enterprises are relatively much younger and have less experience. Moreover, it also highlights the specificity of this newly developed form of ownership, in which experience accumulated on former SOE positions may not be associated with efficiency gains.

\section{The Determinants of Working Hours}

As shown in table 3 , the average number of hours worked per week differs strongly among enterprises of different ownership, the highest being observed for foreign-invested enterprises and the lowest for SOEs at the central or provincial level. To take account of these differences, we estimated equations for working hours, controlling for differences in population structures. We included individual and households characteristics, provincial location, and ownership dummy variables as determinants of the number of hours worked in a

${ }^{17}$ We use the actual number of years of work experience given by the 1995 CHIP survey.

${ }^{18}$ They use data from a firm-based employee survey for the period 1981-87 and estimate total wage equations for 1981 and 1987.

19 They all use the same database (CHIP) for 1995 and provide estimation on pooled data for all types of enterprises. Li (2003) estimates an hourly wage function, while both Knight and Song (2003) and Yueh (2004) estimate total earnings functions. 
TABLE 5

DIFFERENCES IN WORKING HOURS BY OWNERSHIP ENTERPRISES

\begin{tabular}{lccccr}
\hline & \multicolumn{2}{c}{ Men } & & \multicolumn{2}{c}{ Women } \\
\cline { 2 - 3 } & Coefficient & t-Statistic & & Coefficient & t-Statistic \\
\hline Local SOEs & 1.108 & 4.48 & & .430 & 1.62 \\
Urban collectives & 1.711 & 4.43 & & 1.086 & 3.19 \\
Foreign-invested enterprises & 5.314 & 5.46 & & 5.221 & 5.25 \\
No. observations & 5,261 & & 4,723 & \\
\hline
\end{tabular}

Note. Dummy variable coefficients extracted from the estimation of a working hours equation, including individual characteristics (see table A1 of the appendix). The reference category is "state-owned enterprises at central or provincial level."

week. Differences among ownership dummies are assumed to represent mean differences between enterprises, controlling for individual characteristics. ${ }^{20}$

Table 5 presents estimated coefficients for ownership dummy variables for both men and women (the full estimation is given in table A1 of the appendix). The reference category is SOEs at the central or provincial level. As can be seen from these estimates, there are strong differences in the number of hours worked in a week among enterprises of different ownership, after controlling for individual characteristics. ${ }^{21}$ As suggested above, those working in foreigninvested enterprises have a much longer working week than those working in any other type of enterprise. Moreover, among domestic enterprises, central SOEs, which offer higher overall wages, are also found to ask for significantly shorter working hours than local SOEs and urban collectives.

\section{Decomposing Observed Earnings Differentials across Enterprises of Different Ownership}

Following the methodology presented above, we use income function estimations to decompose earnings differentials into what comes from structural socioeconomic differences among workers in the various types of enterprises (pure difference-in-characteristics effects), what comes from the number of hours worked (pure difference-in-hours-worked effect), and what comes from a pure ownership effect. Decomposition results are given in table 6 for the whole population of workers. As discussed above, each "couple" of ownership leads to different simulations depending on the simulation base. The range of simulated effects for each component is thus represented by a corresponding

${ }^{20}$ Estimating different equations for each type of enterprise, as done for earnings functions, represents an undertaking that goes far beyond the scope of this article. Indeed, no valid instruments could be found to explain the choice of enterprise type without affecting working time choices.

${ }^{21}$ All differences are statistically significant at the $1 \%$ level except between local SOEs and urban collectives for which the difference is only significant at the $10 \%$ level for men and at the $5 \%$ level for women. 
TABLE 6

DECOMPOSITION OF OBSERVED EARNINGS DIFFERENTIALS

\begin{tabular}{|c|c|c|c|c|c|c|c|c|c|c|c|c|}
\hline \multirow{2}{*}{\multicolumn{2}{|c|}{ Ownership }} & \multirow{2}{*}{\multicolumn{2}{|c|}{$\begin{array}{l}\text { Average } \\
\text { Earnings }\end{array}$}} & \multirow{3}{*}{$\frac{\begin{array}{c}\text { Observed } \\
\text { Differential }\end{array}}{Y_{A}-Y_{B}}$} & \multicolumn{8}{|c|}{ Effect on the Observed Earnings Differentials of } \\
\hline & & & & & \multicolumn{2}{|c|}{$\begin{array}{c}\text { Characteris- } \\
\text { tics }\end{array}$} & \multicolumn{2}{|c|}{$\begin{array}{c}\text { Ownership + } \\
\text { Hours }\end{array}$} & \multicolumn{2}{|c|}{$\begin{array}{c}\text { Pure } \\
\text { Ownership }\end{array}$} & \multicolumn{2}{|c|}{$\begin{array}{l}\text { Hours } \\
\text { Worked }\end{array}$} \\
\hline A & $B$ & $Y_{A}$ & $Y_{B}$ & & Min & Max & Min & Max & Min & Max & Min & Max \\
\hline CSOEs & LSOEs & 7,006 & 6,248 & 758 & $\begin{array}{l}-104 \\
(-14)\end{array}$ & $\begin{array}{l}-72 \\
(-9)\end{array}$ & $\begin{array}{r}835 \\
(110)\end{array}$ & $\begin{array}{r}859 \\
(113)\end{array}$ & $\begin{array}{r}962 \\
(127)\end{array}$ & $\begin{array}{l}1,011 \\
(133)\end{array}$ & $\begin{array}{l}-152 \\
(-20)\end{array}$ & $\begin{array}{l}-127 \\
(-17)\end{array}$ \\
\hline CSOEs & UCEs & 7,006 & 4,992 & 2,014 & $\begin{array}{l}83 \\
(4)\end{array}$ & $\begin{array}{l}238 \\
(12)\end{array}$ & $\begin{array}{r}1,802 \\
(89)\end{array}$ & $\begin{array}{r}1,915 \\
(95)\end{array}$ & $\begin{array}{r}1,965 \\
(98)\end{array}$ & $\begin{array}{r}2,170 \\
(108)\end{array}$ & $\begin{array}{l}-256 \\
(-13)\end{array}$ & $\begin{array}{r}-163 \\
(-8)\end{array}$ \\
\hline LSOEs & UCEs & 6,248 & 4,992 & 1,256 & $\begin{array}{l}203 \\
(16)\end{array}$ & $\begin{array}{l}306 \\
(24)\end{array}$ & $\begin{array}{l}952 \\
(76)\end{array}$ & $\begin{array}{r}1,052 \\
(84)\end{array}$ & $\begin{array}{r}1,027 \\
(82)\end{array}$ & $\begin{array}{r}1,144 \\
(91)\end{array}$ & $\begin{array}{l}-92 \\
(-7)\end{array}$ & $\begin{array}{l}-75 \\
(-6)\end{array}$ \\
\hline FIEs & CSOES & 8,324 & 7,006 & 1,318 & $\begin{array}{l}194 \\
(15)\end{array}$ & $\begin{array}{l}366 \\
(28)\end{array}$ & $\begin{array}{l}951 \\
(72)\end{array}$ & $\begin{array}{r}1,123 \\
(85)\end{array}$ & $\begin{array}{l}20 \\
(2)\end{array}$ & $\begin{array}{l}196 \\
(15)\end{array}$ & $\begin{array}{l}927 \\
(70)\end{array}$ & $\begin{array}{l}951 \\
(72)\end{array}$ \\
\hline FIEs & LSOEs & 8,324 & 6,248 & 2,076 & $\begin{array}{r}196 \\
(9)\end{array}$ & $\begin{array}{l}346 \\
(17)\end{array}$ & $\begin{array}{r}1,731 \\
(83)\end{array}$ & $\begin{array}{r}1,874 \\
(90)\end{array}$ & $\begin{array}{l}936 \\
(45)\end{array}$ & $\begin{array}{r}1,192 \\
(57)\end{array}$ & $\begin{array}{l}682 \\
(33)\end{array}$ & $\begin{array}{l}802 \\
(39)\end{array}$ \\
\hline FIEs & UCEs & 8,324 & 4,992 & 3,332 & $\begin{array}{l}501 \\
(15)\end{array}$ & $\begin{array}{l}956 \\
(29)\end{array}$ & $\begin{array}{r}2,377 \\
(71)\end{array}$ & $\begin{array}{r}2,831 \\
(85)\end{array}$ & $\begin{array}{r}1,731 \\
(52)\end{array}$ & $\begin{array}{r}2,333 \\
(70)\end{array}$ & $\begin{array}{l}478 \\
(14)\end{array}$ & $\begin{array}{l}694 \\
(21)\end{array}$ \\
\hline
\end{tabular}

Note. Decompositions are based on regressions results presented in tables 4 and 5 . Values refer to measured effects evaluated as earnings differences in yuan. Percentages (in parentheses) refer to measured effects as a percentage of the observed total earnings gap. The CSOEs refer to state-owned enterprises (SOEs) at the central or provincial level, LSOEs to local publicly owned enterprises, UCEs to urban collective enterprises, and FIEs to foreign-invested enterprises.

min-max interval in table 6, measuring the extent to which the simulated effects are sensitive to the choice of the reference ownership and the sequence used for the simulation. ${ }^{22}$ This interval can be considered as a robustness test for our decomposition results.

Our results can be summarized as follows. First, table 6 shows that total earnings gaps among different enterprise ownerships in urban China come from difference-in-ownership and difference-in-hours-worked effects, rather than from differences in characteristics. Indeed, except for urban collectives, whose workers appear to be endowed with much "lower" characteristics, most of the observed earnings gaps can be attributed to the conjunction of differences in ownership and in hours worked. This result confirms that the Chinese labor market is far from fully integrated, leading to large earnings differentials among workers in enterprises of different ownership. Interestingly, our results also show that differences in the number of hours worked are crucial when analyzing earnings differentials between foreign-invested firms, on the one hand, and domestic firms, on the other hand, while it is of a smaller importance in explaining earnings gaps among domestic firms.

${ }^{22}$ Our results are robust to changes in specifications (with different sets of explanatory variables in the wage equations), which have not been reported here. 
Earnings Differentials between Foreign-Invested Enterprises and Domestic Enterprises

Concerning earnings differentials between domestic and foreign enterprises, the observed average earnings gap in favor of the latter ranges from 1,318 yuan per year (central SOEs) to 3,332 yuan per year (urban collectives). Earnings differentials between foreign-invested enterprises and both central and local SOEs are strongly driven by differences in hours worked, which account for more than two-thirds of the gap with central SOEs and one-third of the gap with local SOEs. Besides this strong and robust effect of the number of hours worked, differences in characteristics are in favor of foreign-invested enterprises but explain a lower share of earnings differentials. Finally, and most important, our decomposition results do not show any robust segmentation between foreign-invested enterprises and central SOEs. The pure ownership effect, ranging from 20 to 196 yuan per year, is indeed of a very small magnitude and may even be below the overall precision of reported annual earnings.

As for the comparison between foreign-invested enterprises and urban collectives, the observed earnings gap results from the conjunction of a higher number of hours worked in foreign-invested enterprises, differences in characteristics, and again, a substantial pure ownership effect. This effect accounts for between $52 \%$ and $70 \%$ of the overall observed gaps.

Our results thus confirm that foreign-invested enterprises tend to pay, on average, higher wages than domestic enterprises, albeit they also tend to ask their employees to work more. Higher total annual earnings in foreign-invested enterprises are thus mostly obtained at the cost of a higher number of working hours.

\section{Earnings Differentials among Domestic Enterprises}

Observed earnings gaps are much lower among domestic firms, ranging from 758 yuan per year (between central and local SOEs) to 2,014 yuan per year (between central SOEs and urban collectives). Table 6 shows that observed earnings gaps between SOEs (both central and local) and urban collectives result from the combination of differences in ownership and differences in workers' socioeconomic characteristics, with a much greater importance of the former effect. Differences in the number of hours worked do not appear as an important factor in explaining the gap, and for both central and local SOEs, the difference would even result in higher earnings in urban collectives by $1 \%-5 \%$. Finally, table 6 shows that higher earnings in central SOEs compared to local SOEs are entirely due to segmentation forces, since differences in individual characteristics of workers would even predict a (small) premium in 
favor of local SOEs, as would the difference in hours worked. ${ }^{23}$ These results highlight the much protected situation of workers in SOEs at the central or provincial level in 1995, who were offered higher earnings than workers in other domestic enterprises.

\section{Summary of Decomposition Results}

Our decomposition results show evidence of a nonintegrated hierarchical multitiered labor market in China. Controlling for differences in workers' socioeconomic characteristics and the number of hours worked, foreign-invested enterprises and SOEs at the central or provincial level are the highest-paying enterprises, followed by local SOEs and urban collectives. The pure ownership effect appears to be a key factor in explaining wage gaps among enterprises of different ownership, especially within domestic enterprises. Central SOEs, considered to be the pillar of the economy, appear to be highly protected. However, earnings differences between foreign-invested enterprises and SOEs at the central or provincial level are mostly due to differences in hours worked.

These findings confirm and extend those of previous studies based on different data sets and different methodologies, uncovering some new aspects. First, working time is found to be a key issue in analyzing the segmentation structure of the Chinese labor market. Second, larger SOEs are the most protected segment among domestic enterprises, and their behavior in terms of wage settings differs significantly from other state-owned or collective enterprises. Third, contrary to Zhao $(2001,2002)$, we find no clear segmentation between SOEs at the central or provincial level and foreign-invested enterprises, for which working time differences appear to be the major driving force in explaining observed earnings differentials.

\section{Conclusion}

This article analyzes the determinants of earnings differentials between four categories of enterprises (SOEs at the central or provincial level, local publicly owned enterprises, urban collective enterprises, and foreign-invested enterprises) in urban China in 1995 . We find strong evidence of a nonintegrated multitiered labor market in China in 1995, the conjunction of pure ownership differences and differences in hours worked being the major determinants for observed differences in average earnings among enterprises of different ownership. More specifically, we highlight different paying schemes both among

${ }^{23}$ For the latter, the increase would be of $127-52$ yuan per year, that is to say, an increase in total earnings of about $2 \%$ for workers in local SOEs. 
domestic enterprises and between domestic and foreign enterprises. Different lines of interpretation can be brought to analyze these results.

First, our results provide evidence against a full integration of the Chinese labor market in 1995 among domestic enterprises. We find that the observed earnings gaps between both central and local SOEs and urban collectives come from the combination of a strong ownership effect and differences in workers' characteristics, while the difference between central SOEs and local SOEs is entirely due to the ownership effect. These findings stress the dual nature of the domestic production structure in China, with highly protected enterprises still operating under the rules of the planned economy (central SOEs), on the one hand, and enterprises operating under a mix of market-oriented and planned economy norms (urban collectives and to some extent local SOEs), on the other hand.

Hence, it can be argued from our results that the overprotected SOEs at the central or provincial level were still providing above-market wages to their employees in 1995, as compared to other domestic firms. In this respect, the payment of large subsidies, accounting for nearly $20 \%$ of total earnings in SOE is certainly of crucial importance in accounting for differences among domestic enterprises. In particular, whatever their economic performance, central SOEs were benefiting from preferential institutional factors and were subject to a soft budget constraint, which certainly allowed them to provide higher labor compensations. This interpretation accords with discussions on overemployment in large SOEs and on the slow pace at which other enterprises have been absorbing this excess labor. Indeed, since SOEs at the central or provincial level were providing better payment than any other (domestic) alternatives, it comes as no surprise that local SOEs and urban collectives failed to drive workers out of large SOEs. Following this line of analysis, it can be expected that further reforms of the state sector undertaken since 1995 should have resulted in a decrease in segmentation (market forces playing a greater role in wage determination) and an increase in incentives for turning out of large SOEs.

Second, our results show important earnings differentials between domestic and foreign enterprises in 1995 and FIEs offering much higher total earnings than domestic enterprises. Pure ownership differences and differences in hours worked are the main explanations for these differentials, the contribution of each component varying across enterprises. In particular, the decomposition of the earnings gap with central SOEs reveals that most of the differential is explained by differences in hours worked, while no strong evidence for segmentation in favor of foreign-invested enterprises can be found. Hence, foreigninvested enterprises are offering higher total annual earnings only at the cost 
of higher working hours and not because they provide higher hourly earnings. Furthermore, the differential in terms of hourly earnings would certainly turn in favor of central SOEs if all unobserved nonwage benefits offered by SOEs could be taken into account.

As for the comparison with local SOEs and urban collectives, our results highlight the central role played by the "pure ownership effect" in earnings differentials. However, the issue of the segmentation of the labor market is more complex in this case since different mechanisms are at work, some of which are not to be interpreted purely in terms of segmentation. First, higher earnings received in foreign-invested enterprises can be thought of along the lines of the efficiency wage model, where profit-maximizing foreign-invested enterprises have incentives to pay higher wages in order to "buy" workers' cooperation, boost their effort intensity, and more generally improve the average quality of the pool of job applicants. This is certainly all the more important in the Chinese case, since foreign-invested enterprises face greater difficulties in employee supervision due to language barriers, cultural differences, and so forth.

However, a second major line of interpretation for higher earnings in foreigninvested enterprises can be given in terms of insurance. Indeed, while SOEs, and to a lesser extent urban collectives, were offering better fringe benefits (such as housing), insurance mechanisms (including medical care and pensions), as well as job security in 1995, workers in foreign-invested enterprises were facing strong disadvantages in terms of both social benefits and job security. Therefore, foreign-invested enterprises should be expected to offer higher wages to compensate for the loss of these advantages. However, here the pure ownership effect in favor of foreign-invested enterprises against central SOEs is of a very small magnitude and may well vanish or change sign if all nonwage benefits and insurance mechanisms provided by central SOEs could be taken into account. Again, our results stress the difficulty for foreign-invested enterprises, and more generally for the whole private sector, to drive workers out of large SOEs.

As mentioned above, empirical analyses and interpretations provided in this article only rely on one specific year (1995), access to more recent quality data being still very much restricted. It is thus difficult to draw inferences for the most recent period during which labor market conditions have changed dramatically, especially since SOEs reforms were launched from 1997 onward. However, our finding of a hierarchical, multitiered labor market in China may help in shedding light on evolutions that have been taking place in later years. Our main finding is that the situation in 1995 was such that little spontaneous labor mobility out of large SOEs could be expected. Indeed, the segmentation 
structure was such that workers in large SOEs had no incentives to leave their position and work for other domestic enterprises. Similarly, wages offered by foreign-invested enterprises could not compensate for the loss of social benefits and insurance mechanisms associated with SOE employment. In this context, the necessary shift of the labor force out of the largest, inefficient SOEs to reduce overstaffing and foster competitiveness could only be achieved through the massive layoffs that took place at the end of the 1990s.

\section{Appendix}

TABLE A1 WORKING HOURS DETERMINANTS

\begin{tabular}{|c|c|c|c|c|}
\hline & \multicolumn{2}{|c|}{ Men } & \multicolumn{2}{|c|}{ Women } \\
\hline & Coefficient & $t$-Statistic & Coefficient & t-Statistic \\
\hline Education & -.284 & -6.88 & -.275 & -6.16 \\
\hline Age & .068 & .63 & -.167 & -1.36 \\
\hline $\mathrm{Age}^{2}$ & -.001 & -.89 & .002 & 1.05 \\
\hline No. children under age 6 & .153 & .47 & -.279 & -.87 \\
\hline No. children at school & -.110 & -.41 & -.319 & -1.22 \\
\hline No. dependent members & -.373 & -.92 & .129 & .33 \\
\hline Size of household & 1.346 & 2.05 & 2.021 & 3.04 \\
\hline \multicolumn{5}{|l|}{$\begin{array}{l}\text { Way by which workers got their } \\
\text { current job: }\end{array}$} \\
\hline Employment agency & -.135 & -.13 & 1.227 & 1.57 \\
\hline Inherited & -1.205 & -2.27 & .082 & .18 \\
\hline Self found & .739 & 1.98 & .147 & .46 \\
\hline Other & -.251 & -.43 & -1.219 & -2.51 \\
\hline \multicolumn{5}{|c|}{ Relationship to the head of household: } \\
\hline Spouse & .114 & .44 & .175 & .72 \\
\hline Child & .135 & .24 & -.634 & -1.06 \\
\hline Others & -1.202 & -.89 & .034 & .05 \\
\hline Local SOEs & 1.122 & 4.54 & .431 & 1.62 \\
\hline Urban collectives & 1.671 & 4.33 & 1.088 & 3.20 \\
\hline Foreign-invested enterprises & 5.303 & 5.45 & 5.224 & 5.25 \\
\hline Constant & 41.626 & 16.89 & 45.018 & 16.66 \\
\hline No. observations & 5,261 & & 4,723 & \\
\hline Adjusted $R^{2}$ & .04 & & .05 & \\
\hline
\end{tabular}

Note. The dummy variables by province are not presented in the table.

\section{References}

Adamchick, Vera A., and Arjun S. Bedi. 2000. "Wage Dfferentials between the Public and the Private Sectors: Evidence from an Economy in Transition." Labour Economics 7, no. 2:203-24.

Blinder, Alan S. 1973. "Wage Discrimination: Reduced Form and Structural Estimates." Journal of Human Resources 8, no. 4:436-55.

Bourguignon, François, Martin Fournier, and Marc Gurgand. 2001. "Fast Devel- 
opment with a Stable Income Distribution: Taiwan, 1979-1994." Review of Income and Wealth 47, no. 2:139-63.

Bramall, Chris. 2001. "The Quality of China's Household Income Surveys." China Quarterly 167 (September): 689-705.

Coady, David P., and Limin Wang. 2000. "Equity, Efficiency, and Labor-Market Reforms in Urban China: The Impact of Bonus Wages on the Distribution of Earnings." China Economic Review 11, no. 3:213-31.

Démurger, Sylvie. 2000. Economic Opening and Growth in China. Paris: OECD Development Centre Studies.

Dong, Xiao-Yuan, and Paul Bowles. 2002. "Segmentation and Discrimination in China's Emerging Industrial Labor Market." China Economic Review 13, nos. 2-3:170-96.

Falaris, Evangelos M. 2004. "Private and Public Sector Wages in Bulgaria." Journal of Comparative Economics 32, no. 1:56-72.

Fournier, Martin. Forthcoming. "Exploiting Information from Path Dependency in Oaxaca-Blinder Decomposition Procedures." Applied Economics Letters.

Fu, Yuming, and Stuart Gabriel. 2000. "Location, Market Segmentation, and Returns to Human Capital: The Privatization of China's Labor Markets.” Working Paper no. 2000-1001, Lusk Center for Real Estate, University of Southern California, Los Angeles.

Gustafsson, Björn, and Shi Li. 2000. "Economic Transformation and the Gender Earnings Gap in Urban China.” Journal of Population Economics 13, no. 2:305-29.

Khan, Azizur Rahman, and Carl Riskin. 1998. "Income and Inequality in China: Composition, Distribution and Growth of Household Income, 1988 to 1995." China Quarterly 154:221-53.

Knight, John, and Lina Song. 2003. "Increasing Urban Wage Inequality in China: Extent, Elements and Evaluation." Economics of Transition 11, no. 4:597-619.

Knight, John, Lina Song, and Huaibin Jia. 1999. "Chinese Rural Migrants in Urban Enterprises: Three Perspectives.” In The Workers' State Meets the Market: Labor in China's Transition, ed. Sarah Cook and Margaret Maurer-Fazio. London: Frank Cass.

Li, Haizheng. 2003. "Economic Transition and Returns to Education in China." Economics of Education Review 22, no. 3:317-28.

Lin, Justin Y., Fang Cai, and Zhou Li. 2001. State-Owned Enterprise Reform in China. Hong Kong: Chinese University Press.

Liu, Pak-Wai, Xin Meng, and Junsen Zhang. 2000. "Sectoral Gender Wage Differentials and Discrimination in the Transitional Chinese Economy." Journal of Population Economics 13, no. 2:331-52.

Martins, Pedro S. 2004. "Do Foreign Firms Really Pay Higher Wages? Evidence from Different Estimators.” IZA Discussion Paper no. 1388, Institute for the Study of Labor, Bonn.

Maurer-Fazio, Margaret. 1999. "Earnings and Education in China's Transition to a Market Economy: Survey Evidence from 1989 and 1992." China Economic Review 10, no. 1:17-40.

Maurer-Fazio, Margaret, and Ngan Dinh. 2004. "Differential Rewards to, and Contributions of, Education in Urban China's Segmented Labor Markets." Pacific Economic Review 9, no. 3:173-89. 
Meng, Xin. 2000. Labour Market Reform in China. Cambridge: Cambridge University Press.

Meng, Xin, and Michael P. Kidd. 1997. "Labor Market Reform and the Changing Structure of Wage Determination in China's State Sector during the 1980s." Journal of Comparative Economics 25:403-21.

Meng, Xin, and Junsen Zhang. 2001. "Two-Tier Labor Markets in Urban China: Occupational Segregation and Wage Differentials between Urban Residents and Rural Migrants in Shanghai." Journal of Comparative Economics 29, no. 3:485-504.

Mincer, Jacob. 1974. Schooling, Experience, and Earnings. New York: National Bureau of Economic Research.

Oaxaca, Ronald L. 1973. "Male-Female Wage Differentials in Urban Labor Markets." International Economic Review 14, no. 3:693-709.

Park, Albert, Xiaoqing Song, Junsen Zhang, and Yaohui Zhao. 2003. "The Growth of Wage Inequality in Urban China, 1988 to 1999." Unpublished manuscript, Department of Economics, University of Michigan, Ann Arbor.

Putterman, Louis. 1992. "Dualism and Economic Reform in China." Economic Development and Cultural Change 40, no. 3:467-93.

Riskin, Carl, Renwei Zhao, and Shi Li. 2000. "Chinese Household Income Project, 1995.” Computer file, ICPSR version, Political Economy Research Institute, University of Massachusetts, Amherst (producer), and Inter-University Consortium for Political and Social Research, Ann Arbor, MI (distributor).

- 2001. China's Retreat from Equality: Income Distribution and Economic Transition. London: M. E. Sharpe.

Tansel, Aysit. 2005. "Public-Private Employment Choice, Wage Differentials, and Gender in Turkey." Economic Development and Cultural Change 53, no. 2:453-77.

Yueh, Linda Y. 2004. "Wage Reforms in China during the 1990s." Asian Economic Journal 18, no. 2:149-64.

Zhao, Yaohui. 2001. "Foreign Direct Investment and Relative Wages: The Case of China." China Economic Review 12, no. 1:40-57.

. 2002. "Earnings Differentials between State and Non-state Enterprises in Urban China." Pacific Economic Review 7, no. 1:181-97. 